\title{
PEMANFAATAN VIDEO ONLINE DALAM PEMAHAMAN MATERI PREPOSITION OF TIME AND PLACE (AT, IN, DAN ON)
}

\section{Lilik Yuliawati}

\author{
Universitas Bina Sarana Informatika \\ Jl. Kamal Raya No.18, Ringroad Barat, Cengkareng, Jakarta Barat \\ Surel \& Telepon: lilik.lyw@bsi.ac.id +6283891890989
}

Submitted: 2018-11-12

Accepted: 2019-01-20

Published: 2019-02-01

\begin{tabular}{ll}
\hline Keywords: & Abstract \\
\hline online video & In this high technology era, there are various media which can \\
preposition & be used in teaching and learning activity including English \\
e-learning & Course where students feel difficult to use at, in, and on as \\
& preposition of time and place. Lecturer can combine the \\
& conventional technique through lecturing with online video \\
& playing inside and outside the classroom as the usage of e- \\
& learning concept. This research was held to know the students \\
& perception of online video usage in understanding Preposition of \\
& Time and Place (at, in, and on) material. Descriptive method is \\
& used by using qualitative and quantitative data. Qualitative data \\
& were taken from literature review, whereas quantitative data \\
& were taken from students' test and questionnaire results. The \\
& respondents are 100 students of Bina Sarana Informatika \\
& University majoring Information System who were randomly \\
& chosen. The result of this research shows that most of the \\
& students assume that online video is easily accessible and can \\
& help them review and understand the concept of Preposition of \\
& Time and Place (at,in, and on).
\end{tabular}

\section{PENDAHULUAN}

Dalam perkuliahan selama satu semester ada materi yang harus mahasiswa kuasai dalam mata kuliah Bahasa Inggris, diantaranya yang paling sering dianggap sulit adalah materi tentang preposisi, khususnya Preposition of Time and Place (At, In, and On). Mahasiswa merasa sulit untuk menentukan kapan mereka harus menggunakan preposisi at, in, dan on. Hal itu dapat diketahui melalui pengamatan penulis selama ini dalam mengajar materi tersebut. Mahasiswa sering mengeluhkan kesulitan mereka untuk menempatkan preposisi at, in, dan on dalam kalimat dengan benar.

Dalam konteks waktu preposisi in digunakan untuk menjelaskan waktu yang umum atau memiliki cakupan yang lebih besar, seperti dalam menyebutkan minggu, bulan, tahun, decade, abad, dan suatu periode yang lama. Sebagai contoh: 'in two weeks', 'in July', 'in 1989', 'in the 80's', 'in the next century', 'in summer', dan 'in the Ice Age'. 
Preposisi in juga digunakan untuk beberapa ungkapan standard, seperti 'in the morning', 'in the afternoon', dan 'in the evening'. Adapun preposisi on digunakan untuk menjelaskan waktu yang lebih spesifik dari kata in, misalnya dalam menyebutkan tanggal ataupun hari. Sebagai contoh: 'on 6th March 2017', 'on Monday', dan 'on Independence Day'. Selanjutnya, preposisi at digunakan untuk waktu yang sangat spesifik, misalnya dalam menyebutkan jam. Sebagai contoh: 'at 3 o'clock', 'at 7.45 a.m.', dan 'at 9 p.m.'. Preposisi at juga digunakan untuk beberapa ungkapan standard, seperti 'at noon', 'at night', 'at the weekend', 'at christmas', 'at the same time', dan 'at present'. Namun demikian, preposisi on juga terkadang digunakan dalam menyebutkan 'on the weekend' dan 'on christmas'.

Sementara itu, dalam konteks lokasi atau tempat, preposisi in memiliki ruang lingkup yang sangat umum atau besar, seperti kota, negara, dan benua. Sebagai contoh, 'in Jakarta', 'in New York City', 'in Japan', 'in China', 'in Asia', 'in America'. Selain itu, preposisi in juga digunakan dalam menyebutkan suatu ruang yang tertutup atau memiliki batas, seperti dalam 'in a box', 'in a building', 'in a cup', 'in my pocket', dan 'in the garden'. Adapun, preposisi on digunakan untuk menyebutkan nama jalan, seperti dalam 'on Pine Street' dan 'on Cendana Street'. Selain itu, preposisi on juga digunakan untuk menyebutkan posisi di atas permukaan datar, seperti dalam 'on the wall', 'on the floor', dan 'on the first page'. Selanjutnya, preposisi at digunakan untuk menyebutkan tempat yang sangat spesifik seperti alamat. Sebagai contoh: 'at 1089 Pine Street' dan 'at Cendana Street No.69'. Selain itu, preposisi at juga digunakan untuk menyatakan posisi yang spesifik pada sebuah titik tertentu, seperti dalam 'at the corner', 'at the bus stop', dan 'at school'.

Kesulitan dalam penggunaan preposisi dalam Bahasa Inggris ternyata juga dialami oleh banyak orang, seperti yang terlihat dari beberapa penelitian terdahulu. Kesalahan pada penggunaan preposisi at, in, dan on sering kali terjadi, yakni preposisi in dan at lebih sering muncul dibandingkan on (Suzanne, 2017). Kesalahan tersebut diantaranya dipengaruhi oleh bahasa ibu atau bahasa kedua siswa. Hal ini ditegaskan juga oleh peneliti lain dimana para ahli berpendapat bahwa preposisi merupakan salah satu unsur dalam Bahasa Inggris yang sering membingungkan para pengguna bahasa, terutama mereka yang sistem preposisi bahasa ibunya berbeda dengan preposisi Bahasa Inggris (Khotaba \& Karak, 2013). Kesulitan dalam memahami materi Preposition of Time and Place (at, in, and on) ini dialami oleh banyak orang, baik pada siswa sekolah tingkat awal, menengah, atas, maupun pada mahasiswa di perguruan tinggi. Oleh karena itu, perlu dicarikan solusi agar materi preposisi ini dapat lebih mudah dipahami. Salah satunya dengan cara memperkaya media pembelajaran dengan memanfaatkan kemajuan teknologi yang ada saat ini.

Dalam era internet sekarang ini, mahasiswa dapat memanfaatkan banyak media untuk membantu mereka dalam memahami materi perkuliahan. Mahasiswa dapat mencari informasi dan belajar secara mandiri melalui berbagai aplikasi dan situs yang dapat mereka jelajahi dengan internet sebagai salah satu bentuk pemanfaatan e-learning. Elearning didefinisikan sebagai pembelajaran dengan memanfaatkan teknologi elektronik sebagai sarana penyajian dan distribusi informasi, seperti radio, televisi, dan yang paling populer saat ini adalah teknologi internet (Sabar \& Rahman, 2011). Definisi e-learning juga dijabarkan oleh Muzid \& Munir (2005) sebagai sebuah sistem pembelajaran yang memanfaatkan kelebihan yang dimiliki internet dengan memberikan kebebasan waktu dan tempat, serta tidak hanya berpusat pada tenaga pengajar.

Salah satu situs berbagi video yang paling populer saat ini adalah Youtube (Snelson, 2011) yang di dalamnya mereka dapat menonton berbagai video online secara gratis. Selain video yang bersifat hiburan, banyak pula video edukasi yang tersedia dalam situs 
tersebut. Cukup banyak video edukasi online yang didesain sangat komunikatif, informatif, dan menarik sehingga dapat menarik minat mahasiswa untuk menonton. Berdasarkan penelitian yang dilakukan oleh Lestari (2017), pengintegrasian Youtube di kelas Bahasa Inggris sangat membantu pengayaan materi bagi pembelajaran karena berhasil menambah minat dan ketertarikan mahasiswa sehingga mata kuliah ini tidak lagi dianggap sebagai mata kuliah yang sulit dipelajari. Oleh karena itu, digunakanlah teknik pembelajaran yang menggabungkan kuliah/ceramah yang diberikan oleh dosen dengan pemutaran video online sebagai salah satu bentuk pemanfaatan teknologi internet. Hal ini dilakukan dengan harapan siswa dapat belajar secara mandiri mengenai Preposition of Time and Place (at, in, and on) melalui video online yang dapat mereka tonton kembali di luar jam kuliah sehingga mereka lebih mudah memahami materi tentang penggunaan preposisi.

Penelitian ini dilakukan untuk mengetahui persepsi mahasiswa tentang sejauh mana video online dapat membantu mereka memahami materi Preposition of Time and Place (at, in, and on) dan hasilnya diharapkan dapat digunakan sebagai masukan bagi tenaga pengajar dalam mengembangkan media pembelajaran dalam upaya mempermudah mahasiswa dalam memahami materi.

\section{METODE PENELITIAN}

Penelitian ini dilaksanakan pada tanggal 24 September 2018 sampai dengan 12 Oktober 2018 di Universitas Bina Sarana Informatika. Metode yang digunakan dalam penelitian ini merupakan metode deskriptif yang jenis data yang digunakan merupakan data kualitatif dan data kuantitatif. Data kualitatif merupakan data yang diambil dari studi pustaka. Adapun data kuantitatif merupakan data yang berasal dari hasil tes mahasiswa dengan materi Preposition of Time and Place (at, in, and on) dan jawaban kuesioner mahasiswa. Tes dengan materi Preposition of Time and Place (at, in, and on) dilakukan untuk melihat kemampuan dan pemahaman mahasiswa tentang materi tersebut yang selanjutnya hasil tes ini dikonfirmasikan kepada mahasiswa melalui kuesioner. Ada dua jenis kuesioner yang dibagikan, yaitu kuesioner mengenai pemahaman mahasiswa pada materi Preposition of Time and Place (at, in, dan on) dan kuesioner mengenai persepsi mahasiswa terhadap video online sebagai media dalam memahami materi tersebut.

Responden dalam penelitian ini merupakan mahasiswa Jurusan Sistem Informasi Universitas Bina Sarana Informatika yang berada pada semester satu dan mendapatkan mata kuliah Bahasa Inggris I sebagai mata kuliah umum. Responden dipilih secara acak sebanyak 100 mahasiswa.

Secara singkat prosedur penelitian dapat dituliskan sebagai berikut: (1) Ceramah dosen di kelas, (2) Tes, (3) Kuesioner tentang pemahaman mahasiswa, (4) Pemutaran video online, (5) Pemberian tugas kepada mahasiswa untuk menonton tiga video online lainnya di luar jam perkuliahan, dan (6) Pengisian kuesioner tentang persepsi mahasiswa.

\section{HASIL DAN PEMBAHASAN}

Pemahaman Mahasiswa pada Materi Preposition of Time and Place (at, in, and on)

Berdasarkan hasil tes dengan materi Preposition of Time and Place (at, in, and on) yang dikerjakan oleh mahasiswa, didapat hasil sebagai berikut. 
Tabel 1. Hasil Tes Mahasiswa

\begin{tabular}{cc}
\hline Rentang Nilai & Jumlah Mahasiswa \\
\hline $91-100$ & 0 \\
$81-90$ & 4 \\
$71-80$ & 10 \\
$61-70$ & 15 \\
$51-60$ & 39 \\
$41-50$ & 25 \\
$31-40$ & 5 \\
$21-30$ & 2 \\
$11-20$ & 0 \\
$0-10$ & 0 \\
\hline Total & $\mathbf{1 0 0}$ \\
\hline
\end{tabular}

Dari tabel 1 tersebut dapat dilihat bahwa dari total 100 mahasiswa yang mengikuti tes, sebanyak 86 mahasiswa masih mendapatkan nilai di bawah 71 . Hal ini menunjukkan bahwa sebagian besar mahasiswa memiliki kesulitan dalam mengerjakan soal-soal Preposition of Time and Place (at, in, and on). Dengan kata lain, hanya sebagian kecil mahasiswa yang cukup memahami materi tersebut. Ada sebanyak 10 mahasiswa yang mampu mendapatkan nilai dalam rentang 71-80 dan hanya 4 mahasiswa yang berhasil mendapatkan nilai di atas 80 .

Setelah dikonfirmasikan melalui kuesioner yang dibagikan kepada 100 mahasiswa yang mengerjakan tes tersebut, sebagian besar mahasiswa mengaku mengalami kesulitan dalam membedakan dan menggunakan preposisi at, in, dan on dengan benar. Hal tersebut nampak pada tabel 2 .

Tabel 2. Hasil Kuesioner tentang Pemahaman Mahasiswa

\begin{tabular}{clccccc}
\hline \multirow{2}{*}{ No. } & \multicolumn{1}{c}{ Pernyataan } & SS & S & TS & SS & Total \\
\hline 1 & $\begin{array}{l}\text { Saya mengalami kesulitan dalam } \\
\text { membedakan preposisi at, in, dan } \\
\text { on. }\end{array}$ & 13 & 69 & 15 & 3 & $\mathbf{1 0 0}$ \\
\hline 2 & $\begin{array}{l}\text { Saya tidak tahu kapan harus } \\
\text { menggunakan preposisi at, in, dan } \\
\text { on dalam kalimat. }\end{array}$ & 12 & 64 & 24 & - & $\mathbf{1 0 0}$ \\
\hline 3 & $\begin{array}{l}\text { Saya tidak mengetahui secara pasti } \\
\text { makna dari preposisi at, in, dan } \text { on. }\end{array}$ & 12 & 65 & 21 & 2 & $\mathbf{1 0 0}$ \\
\hline 4 & $\begin{array}{l}\text { Saya mengalami kesulitan dalam } \\
\text { mengerjakan soal tes dengan materi } \\
\text { preposisi at, in, dan } \text { on. }\end{array}$ & 18 & 61 & 21 & - & $\mathbf{1 0 0}$ \\
\hline
\end{tabular}

Tabel 2 menjelaskan bahwa lebih dari 75\% mahasiswa mengalami kesulitan dalam membedakan preposisi $a t$, in, dan on dan tidak mengetahui kapan harus menggunakan preposisi tersebut dalam kalimat. Terlebih lagi mereka juga tidak mengetahui secara pasti makna dari preposisi $a t$, in, dan on sehingga mengalami kesulitan dalam mengerjakan soal-soal tes dengan materi Preposition of Time and Place (at,in, and on). 


\section{Persepsi Mahasiswa terhadap Pemanfaatan Video Online}

Hasil dari kuesioner yang diberikan kepada 100 mahasiswa menunjukkan bahwa sebagian besar mahasiswa memiliki persepsi yang positif terhadap pemanfaatan video online dalam membantu mereka memahami materi tentang Preposition of Time and Place (at,in, and on) seperti yang terlihat pada tabel 3.

Tabel 3. Hasil Kuesioner tentang Persepsi Mahasiswa

\begin{tabular}{|c|c|c|c|c|c|c|}
\hline \multirow[b]{2}{*}{ No. } & \multirow[b]{2}{*}{ Pernyataan } & \multicolumn{4}{|c|}{ Jumlah Jawaban } & \multirow[b]{2}{*}{ Total } \\
\hline & & SS & $\mathbf{S}$ & TS & $\begin{array}{c}\text { ST } \\
\text { S }\end{array}$ & \\
\hline 1 & Video online mudah diakses. & 73 & 26 & 1 & 0 & 100 \\
\hline 2 & $\begin{array}{l}\text { Video online membantu saya } \\
\text { dalam menambah pengetahuan } \\
\text { Bahasa Inggris. }\end{array}$ & 43 & 56 & 1 & 0 & 100 \\
\hline 3 & $\begin{array}{l}\text { Video online menyajikan materi } \\
\text { preposition of time and place } \\
\text { dengan visualisasi yang menarik. }\end{array}$ & 36 & 59 & 5 & 0 & 100 \\
\hline 4 & $\begin{array}{l}\text { Video online menyajikan materi } \\
\text { preposition of time and place } \\
\text { dengan penjelasan yang mudah } \\
\text { dipahami. }\end{array}$ & 21 & 67 & 12 & 0 & 100 \\
\hline 5 & $\begin{array}{l}\text { Video online memudahkan saya } \\
\text { untuk mengkaji kembali materi } \\
\text { preposition of time and place yang } \\
\text { disampaikan dosen di kelas. }\end{array}$ & 40 & 51 & 9 & 0 & 100 \\
\hline 6 & $\begin{array}{l}\text { Video online memudahkan saya } \\
\text { untuk memahami konsep } \\
\text { penggunaan preposition of time } \\
\text { and place. }\end{array}$ & 20 & 72 & 7 & 1 & 100 \\
\hline 7 & $\begin{array}{l}\text { Video online membantu saya } \\
\text { dalam mengerjakan soal-soal } \\
\text { tentang preposition of time and } \\
\text { place. }\end{array}$ & 29 & 62 & 8 & 1 & 100 \\
\hline 8 & $\begin{array}{l}\text { Video online efektif } \\
\text { meningkatkan kualitas } \\
\text { pembelajaran }\end{array}$ & 41 & 54 & 4 & 1 & 100 \\
\hline
\end{tabular}

Dari tabel 3 dapat dilihat bahwa sebanyak 99 mahasiswa setuju bahwa video online mudah diakses. Selanjutnya, lebih dari 85 mahasiswa menjawab setuju pada setiap butir pernyataan nomor 2 sampai dengan 8 . Ini artinya, sebagian besar mahasiswa merasa terbantu dengan adanya video online yang mampu menyajikan materi dengan visualisasi yang menarik sehingga mereka dapat memanfaatkan video online tersebut untuk mengkaji kembali materi pelajaran yang diberikan oleh dosen di kelas, khususnya tentang Preposition of Time and Place (at,in, and on).

Sampai saat ini materi tentang Preposition of Time and Place (at, in, and on) masih menjadi salah satu materi yang dianggap sulit oleh mahasiswa. Mahasiswa belum menguasai konsep penggunaan preposisi at, in, dan on sehingga mereka mengalami kesulitan dalam menggunakan preposisi tersebut dalam kalimat. Permasalahan ini juga ditemukan dalam penelitian sebelumnya. Siswa merasa bingung dalam menggunakan preposisi in dan on serta mereka tidak mengalami perkembangan yang signifikan dari satu 
jenjang pendidikan ke satu jenjang yang lain yang lebih tinggi (Arjan; Roslim, 2013). Hal serupa juga terjadi pada penutur asli Bahasa Arab yang menghasilkan beragam kesalahan dalam penggunaan preposisi. Berdasarkan hasil analisis, kesalahan yang dibuat sebagian besar terjadi pada fungsi dan penempatan preposisi yang dipengaruhi oleh bahasa ibu dan ketidakcukupan pengetahuan siswa terhadap konsep preposisi dalam Bahasa Inggris (Khotaba; Karak, 2013).

Berdasarkan hasil pengisian kuesioner yang dibagikan kepada 100 mahasiswa, terlihat bahwa sebagian besar mahasiswa memiliki persepsi yang positif terhadap pemanfaatan video online dalam upaya membantu mereka untuk menguasai materi Preposition of Time and Place (at, in, and on). Lebih dari 90 mahasiswa setuju bahwa video online dapat diakses dengan mudah dan disajikan dengan visualisasi yang menarik. Hal ini sesuai dengan yang disampaikan dalam penelitian Lestari (2017) bahwa video online sangat mudah ditonton dan diunduh salah satunya dengan menggunakan situs web berbagi video Youtube. Youtube menyajikan materi dengan gambar visual yang menarik dan dapat digunakan sebagai media pembelajaran mata kuliah yang dianggap sulit bagi mahasiswa. Salah satunya adalah mata kuliah umum Bahasa Inggris. Lebih jauh lagi, Yuliawati (2018) juga mengungkapkan bahwa konten pelajaran pada sebuah aplikasi yang didukung dengan multimedia seperti gambar, audio, video, dan animasi mampu membantu mahasiswa dalam meningkatkan kemampuan Bahasa Inggris.

Selanjutnya, sebanyak lebih dari 90 mahasiswa juga menyatakan setuju bahwa video online memudahkan mereka dalam mengkaji kembali serta memahami konsep penggunaan Preposition of Time and Place (at, in, and on) yang telah disampaikan oleh dosen di kelas karena mereka dapat menonton kembali video-video tersebut di luar jam kuliah kapan pun mereka mau. Hasil penelitian ini selaras dengan penelitian sebelumnya dimana sebanyak $88,9 \%$ mahasiswa menyatakan bahwa video dari Youtube membantu mereka dalam memahami materi dengan lebih baik (Lestari, 2017).I

\section{SIMPULAN}

Sebagian besar mahasiswa belum mengetahui makna dan konsep materi Preposition of Time and Place (at, in, and on) dengan baik sehingga hasil yang terlihat dalam tes belumlah memuaskan. Dengan keterbatasan waktu yang dimiliki oleh dosen untuk menjelaskan materi di dalam kelas, video online menjadi pelengkap media pembelajaran yang cukup menarik dan dapat ditonton serta diunduh oleh mahasiswa dengan mudah. Sebagian besar mahasiswa memiliki persepsi yang positif terhadap pemanfaatan video online dalam membantu mereka memahami materi Preposition of Time and Place (at, in, and on). Oleh karena itu, dosen diharapkan dapat memperkaya media pembelajaran yang digunakan dan mengkombinasikan teknik pengajaran secara konvensional dengan pemanfaatan video online untuk membantu mahasiswa memahami materi.

\section{DAFTAR PUSTAKA}

Arjan, A., Abdullah, N.H., \& Roslim, N.(2013). A Corpus-Based Study on English Prepositions of Place. English Language Teaching, 6 (12), 167-174. https://doi.org/10.5539/elt.v6n12p167.

Khotaba, E. Al \& Karak, A. (2013). Errors in the Use of Prepositions and Adverb Particles by Arab ESL Speakers: Performance Analysis Perspective. International Journal of Linguistics, 5(1), 273-282. https://doi.org/10.5296/ijl.v5i1.3310.

Lestari, R. (2017). "Penggunaan Youtube sebagai Media Pembelajaran Bahasa Inggris." Prosiding Seminar Nasional Kedua Pendidikan Berkemajuan dan Menggembirakan: 607-612. 
Muzid, S.\& Munir, M. (2005). Persepsi Mahasiswa dalam Penerapan E-Learning sebagai Aplikasi Peningkatan Kualitas Pendidikan. Seminar Nasional Aplikasi Teknologi Informasi 2005: A-27 - A-34.

Sabar, K. \& Rahman, A.(2011). Penggunaan Web ( E-Learning ) dalam Proses Pembelajaran Bahasa Inggris di Briton International English School Makassar. Jurnal Komunikasi KAREBA, 1(4), 444-456.

Snelson, C.(2011). YouTube across the Disciplines: A Review of the Literature." MERLOT Journal of Online Learning and Teaching, 7(1), 159-169.

Yuliawati, L.(2018). Pemanfaatan Mobile Assisted Language Learning ( MALL ) melalui Aplikasi Berbasis Android dalam Pembelajaran Bahasa Inggris secara Mandiri. Prosiding Seminar KALUNI, 1: 60-65. 